\title{
Terminal Body Weight
}

National Cancer Institute

\section{Source}

National Cancer Institute. Terminal Body Weight. NCI Thesaurus. Code C90464.

The weight of a subject at a specified end point. 